\title{
HAMBATAN KOMUNIKASI EFEKTIF PERAWAT DENGAN KELUARGA PASIEN DALAM PERSPEKTIF PERAWAT
}

\author{
${ }^{1}$ Dinda Piranti Arumsari, ${ }^{2}$ Etika Emaliyawati, ${ }^{3}$ Aat Sriati \\ ${ }^{1,2,3}$ Fakultas Keperawatan Universitas Padjadjaran \\ Email: 1dindapiranti@yahoo.co.id; ${ }^{2}$ etika@unpad.ac.id
}

\begin{abstract}
ABSTRAK
Komunikasi merupakan sebuah proses yang sangat penting dalam hubungan antar manusia. Di dalam memberikan pelayanan keperawatan, perawat harus memiliki pengetahuan dan kemampuan berkomunikasi yang baik sebagai awal terciptanya sebuah hubungan perawat dengan pasien dan keluarga. perawat yang memiliki kemampuan dan keterampilan yang baik dalam berkomunikasi akan mudah menjalin hubungan dengan pasien maupun keluarga. Penelitian ini bertujuan untuk melihat hambatan komunikasi efektif perawat dengan keluarga pasien dalam perspektif perawat di Intensive Care Unit Rumah Sakit Umum Al Islam Bandung. Penelitian deskriptif exploratif ini melibatkan 10 orang perawat yang diambil menggunakan accidental sampling. Data diambil dengan melakukan wawancara dan observasi, kemudian dianalisis menggunakan content analysis. Hasil penelitian menujukkan bahwa terdapat lima tema yang menjadi hambatan komunikasi efektif perawat dengan keluarga pasien dalam perspektif perawat di Intensive Care Unit Rumah Sakit Umum Al Islam Bandung yaitu konflik peran, faktor demografi keluarga, kesalahpahaman, lingkungan dan situasi di ICU, dan kondisi psikologis keluarga. Dengan demikian, pelatihan terkait komunikasi perawat dengan keluarga pasien menjadi penting untuk dilaksanakan dalam upaya meningkatkan kemampuan perawat seperti kemampuan berbahasa asing dan kesabaran dalam menghadapi situasi dan kondisi di ICU khususnya berhubungan dengan keluarga pasien. Hal ini dikarenakan perawat adalah ujung tombak dalam pemberian pelayanan di Rumah Sakit.
\end{abstract}

Kata Kunci : Hambatan, ICU, Keluarga pasien, Komunikasi efektif \& Perawat

\section{ABSTRACT}

Communication is a very important process in human relationship. In providing nursing care, nurses should have a good knowledge and communication skill as the beginning of a good relationship between nurses, patients, and their families. Nurses with good communication skill had an easier opportunity to make a good relationship with the patient and their families. This study aimed to identify effective communication barriers among nurses in developing communication with patients' family according to nurses' perspective in Intensive Care Unit Rumah Sakit Umum Al Islam Bandung. This descriptive explorative study involved 10 nurses were taken with accidental sampling. Data were gathered using interview and observation. Data analyzed with the content analysis. Result showed that there were at least five topic of effective communication barriers among nurses in developing communication with patients' family according to nurses' perspective in Intensive Care Unit Rumah Sakit Umum Al Islam Bandung; role conflict, family demographic factors, misunderstanding, environment and situation in the ICU, and family psychological condition. So, training related to communication between nurses and patients' family were necessary to undertake in order to improve the ability of nurses such as foreign language skills and patience in dealing with the situation in the ICU especially in relation to the patient's family. This is because nurses are the spearhead of health care service in hospital.

Keywords: Barriers, ICU, the patient's family, effective communication, \& nurse 


\section{PENDAHULUAN}

Perawat merupakan salah satu ujung tombak dalam pemberian pelayanan kesehatan di Rumah Sakit. Hal ini menjadi sebuah tuntutan peran dan juga fungsi perawat untuk memberikan sebuah pelayanan asuhan keperawatan yang berkualitas untuk memenuhi kebutuhan pasien. Di dalam memberikan pelayanan keperawatan, perawat dituntut untuk memiliki pengetahuan dan kemampuan berkomunikasi yang baik sebagai awal dari terciptanya sebuah hubungan perawat dengan klien, karena komunikasi merupakan sebuah proses yang sangat penting dalam hubungan antar manusia.

Perawat yang memiliki kemampuan dan keterampilan baik dalam hal berkomunikasi akan mudah menjalin hubungan dengan pasien maupun keluarga (Liljeroos, Snellman, \& Ekstedt, 2011). Komunikasi yang baik dan benar merupakan poin penting yang harus dimiliki oleh setiap tenaga kesehatan, khususnya perawat. Komunikasi dibutuhkan oleh perawat dalam memberikan pelayanan asuhan keperawatan baik kepada pasien maupun keluarga. Kemampuan seperti ini penting dan harus ditumbuhkembangkan oleh perawat, sehingga menjadi suatu kebiasaan dalam setiap menjalankan tugasnya dalam memberikan pelayanan kesehatan di Rumah Sakit.

Menurut Suryani (2014), komunikasi berperan dalam kesembuhan klien, berhubungan dalam kolaborasi yang dilakukan perawat dengan tenaga kesehatan lainnya, dan juga berpengaruh pada kepuasan klien dan keluarga. Hal tersebut menjadikan komunikasi dibutuhkan di setiap bentuk pelayanan yang ada di Rumah Sakit. Salah satu bentuk pelayanan yang ada di Rumah Sakit adalah ruangan intensive care unit (ICU) yaitu sebuah bentuk pelayanan khusus pada pasien-pasien yang mengalami kondisi kritis.

Intensive care unit adalah unit perawatan khusus yang dikelola untuk merawat pasien sakit berat dan kritis, cedera dengan penyulit yang akan mengancam nyawa atau berpotensial mengancam nyawa dengan melibatkan tenaga kesehatan terlatih serta didukung dengan kelengkapan peralatan khusus yang ditujukan untuk observasi, perawatan, dan terapi pasien-pasien (Depkes, 2006; Kepmenkes, 2010).

Kondisi pasien yang tidak stabil dan umumnya mengalami penurunan kesadaran, menjadikan keluarga sebagai pihak penting dalam pembuat keputusan yang berkaitan dengan tindakan keperawatan. Dalam kondisi seperti itu, tentunya dibutuhkan komunikasi yang efektif antara perawat dan keluarga.

Sebuah penelitian yang dilakukan oleh Ghiyasvandian, Zakerimoghadam, dan Peyravi (2015) di Iran yang menyatakan bahwa perawat merupakan inti dalam komunikasi dan memainkan peranan penting dalam memfasilitasi komunikasi yang profesional, hal ini dikarenakan perawat merupakan jembatan penghubung antara pasien dan keluarga dengan tenaga kesehatan profesional lainnya.

\section{METODE}

Metode penelitian yang digunakan dalam penelitian ini adalah deskriptif eksploratif. Penelitian kualitatif berfokus dalam menjelaskan dan memberi pemahaman dan interpretasi tentang berbagai perilaku dan pengalaman manusia (individu) dalam berbagai bentuk (Afiyanti \& Rachmawati, 2014).

Peneliti menggunakan metode kualitatif karena masih sedikit sekali informasi mengenai komunikasi efektif yang dilakukan oleh perawat. Metode ini merupakan metode yang digunakan untuk mendapatkan pengetahuan awal dari suatu fenomena.

Pendekatan deskriptif kualitatif dengan studi eksplorasi adalah melakukan penyelidikan tentang makna dari suatu peristiwa hidup untuk sekelompok orang. Pendekatan deskriptif eksploratif pada penelitian ini adalah untuk mengungkap hambatan komunikasi efektif perawat dengan keluarga pasien dalam perspektif perawat di 
Intensive Care Unit (ICU) Rumah Sakit Umum Al Islam Bandung.

Instrumen penelitian ini terbagi menjadi empat komponen yaitu peneliti sebagai instrumen utama, pedoman wawancara, pedoman observasi, dan alat perekam suara (voice recorder). Pengumpulan data dilakukan dengan menggunakan wawancara semi terstruktur (semi structured interview) selama 30-60 menit untuk masing-masing informan. Informan pada penelitian ini diperoleh dengan menggunakan teknik accidental sampling, yaitu metode pemilihan atau pengambilan sampel sumber data dengan jalan mengambil individu siapa saja yang dapat dijangkau atau ditemui (Polit dan Beck, 2014; Sugiyono, 2014). Dalam penelitian ini informan adalah 10 orang perawat yang bekerja di ICU Rumah Sakit Umum Al Islam Bandung.

Analisa data menggunakan analisa konten (content analysis). Content analysis merupakan sebuah prosedur untuk mengkategorikan data verbal atau perilaku, untuk tujuan klasifikasi, membuat ringkasan dan perhitungan. Merujuk pada Hancock (2002), konten tersebut dapat dianalisa pada 2 tingkat. Analisa tingkat dasar adalah pertimbangan deskriptif mengenai data yang didalamnya membahas mengenai apa yang sesungguhnya dikatakan tanpa asumsi. Analisis konten melibatkan coding dan pengelompokkan data. Hal ini untuk mengidentifikasi hasil dari transkrip.

\section{HASIL DAN PEMBAHASAN}

Berdasarkan penelitian yang dilakukan kepada 10 orang perawat yang bekerja di Intensive Care Unit (ICU) Rumah Sakit Umum Al Islam Bandung didapatkan hasil yaitu :

Tabel 1. Karakteristik responden

\begin{tabular}{ccccc}
\hline Informan & Jenis Kelamin & Usia & Pendidikan & Lama Bekerja di ICU \\
\hline 1 & Laki-Laki & 26 tahun & D3 Keperawatan & 6 tahun \\
2 & Perempuan & 37 tahun & D3 Keperawatan & 6 tahun \\
3 & Perempuan & 38 tahun & D3 Keperawatan & 5 tahun \\
4 & Perempuan & 39 tahun & D3 Keperawatan & 8 tahun \\
5 & Perempuan & 36 tahun & D3 Keperawatan & 3 tahun \\
6 & Laki-Laki & 40 tahun & D3 Keperawatan & 4 tahun \\
7 & Laki-Laki & 39 tahun & D3 Keperawatan & 4 tahun \\
8 & Laki-Laki & 29 tahun & D3 Keperawatan & 7 tahun \\
9 & Laki-Laki & 33 tahun & D3 Keperawatan & 3 tahun \\
\hline
\end{tabular}

\section{Karakteristik Responden}

Setengah dari informan berjenis kelamin laki-laki dan setengahnya lagi adalah berjenis kelamin perempuan. Dengan rentang usia minimal adalah 26 tahun dan maksimal usia informan adalah 40 tahun. Seluruh informan memilikilatar belakang pendidikan yang sama yaitu D3 keperawatan dengan minimal lama bekerja di ICU adalah tahun dan maksimal lama bekerja di ICU adalah 8 tahun.

\section{Hambatan komunikasi efektif perawat dengan keluarga pasien}

Dari 10 orang informan yang diwawancara terkait hambatan yang dialami perawat dalam berkomunikasi dengan keluarga pasien didapatkan lima tema yaitu konflik peran, faktor demografi keluarga, kesalahpahaman, lingkungan dan situasi di ICU, dan kondisi psikologis keluarga.

\section{Konflik peran}

Hal ini diungkapkan oleh seluruh informan bahwa 10 perawat yang 
diwawancara menyatakan tidak enak dan menjadi malas saat berkomunikasi dengan keluarga pasien dikarenakan keluarga pasien terkadang bersikap jutek seperti yang diungkapkan oleh beberapa informan di bawah ini.

“....... cuma ya jadi males ke kitanya gitu kan nggak enak kan ya ngomong sama orang tapi mukanya jutek gitu" (P2)

“....... ya jadi nggak enak aja gitu ke kitanya juga kadang suka rada males tapi ya mau gimana lagi kan da tugas perawat kan emang gitu jadi kalo ada yang nggak enak yaudah" (P3)

“........ kadang ke kitanya jadi ikutan BT juga ......"(P7)

Dilema komunikasi yang dirasakan oleh perawat tidak hanya terkait sikap yang ditunjukkan oleh keluarga pasien saat berhadapan dengan mereka saja melainkan juga kondisi psikologis dan fisik mereka seperti ketika mereka sedang lelah atau saat sedang ada masalah pribadi terkadang perawat sering melupakan penampilannya saat berkomunikasi dengan keluarga pasien. Hal tersebut tentunya dapat menjadi penghambat perawat dalam berkomunikasi dengan keluarga pasien. Beberapa informan menyatakan adanya kondisi dimana terkadang mereka sering melupakan penampilan mereka di depan keluarga pasien seperti yang diungkapkan oleh 4 orang dari 10 informan yang diwawacara

"Kalo lupa senyum kaya gitu da pasti pernah apalagi capek-capeknya atau kaya lagi ada masalah di rumah ....." (P2)

“....... kitanya capek anggepan keluarganya kok judes padahal mah nggak judes mungkin dia lagi capek ada kalanya kita megang dua pasien" (P8)

Kondisi pasien yang tidak sadar di ICU menjadikan keluarga sebagai penanggung jawab pasien dalam tindakan apapun termasuk didalamnya yaitu berkomunikasi dengan perawat. Dalam hal ini tentunya dibutuhkan komunikasi yang efektif mengingat keluarga sebagai jembatan penghubung antara perawat dengan pasien. Hal ini seperti yang diungkapkan oleh 4 orang dari 10 informan yang diwawancara

“...... penanggung jawab pasien tuh ya anaknya .....” (P3)

“....... misal belum ngerti aja kita cari anaknya ada kemungkinan di GC itu ada anaknya" (P4)

“..... biasanya suka manggil anggota keluarganya yang lain yang lebih paham ......" (P5)

“...... ya kita nanya lagi ke keluarga intinya ada anggota yang lain nggak yang kira-kira lebih ngerti ......" (P8)

Kondisi pasien yang tidak stabil menjadikan keluarga diwajibkan untuk selalu berjaga di ruang tunggu. Hal ini dikarenakan kondisi pasien di ICU sangatlah fluktuatif artinya keadaan pasien dapat tiba-tiba membaik atau malah mungkin menjadi menurun. Oleh karena itu pasien yang berada di ICU wajib ditunggui oleh keluarganya di ruang tunggu.

Beberapa perawat menyatakan bahwa terkadang keluarga meninggalkan pasien atau tidak ada ditempat sehingga hal tersebut menyulitkan perawat dalam memberikan informasi. Hal ini seperti yang diungkapkan oleh 3 orang dari 10 informan di bawah ini

“...... karna kalo ada kejadian kita suka agak marah kalo pasien udah usia lanjut keluarganya pada pulang ......" (P6)

“...... kendalanya sama ya itu tadi dikasih nomer kontak tapi ditelepon nggak diangkat-angkat ......" (P8)

“...... kesulitannya disini sih jadi komunikasi tuh emang nggak bisa terusterusan dimana ada peluang komunikasi eh keluarganya lagi nggak ada ....." (P8)

“...... kadang-kadang ada yang nggak ditunggu alesannya sibuk, ada kerja, ada yang punya anak kecil ......” (P10)

\section{Faktor Demografi Keluarga}

Dari hasil analisa data muncul tiga sub tema terkait faktor demografi keluarga yang berhubungan dalam komunikasi antara 
perawat dengan keluarga pasien di ICU yaitu usia, pendidikan, dan ekonomi.

\section{1) Usia}

Usia menjadi salah satu faktor demografi keluarga yang mempengaruhi komunikasi. Hal ini dikarenakan cara kita berkomunikasi dengan orang lain tentunya disesuaikan dengan faktor demografi orang tersebut salah satunya adalah usia.

Dalam hal ini kita sebagai perawat harus bisa menyesuaikan dan menempatkan diri dengan adanya perbedaan usia antara perawat dengan keluarga pasien baik itu kepada yang lebih muda, sebaya, maupun kepada yang lebih tua. Hal tersebut diungkapkan oleh 7 orang dari 10 informan yang diwawancara dengan beberapa kutipan informan di bawah ini

“...... udah sepuh kan ya pasti rada sulit sih kan harus ngejelasinnya pelan-pelan ......." (P4)

“...... harus dengan menggunakan bahasa sederhana pokoknya yang mudah dimengerti sama mereka ......" (P5)

“....... harus pelan-pelan banget, diulang-ulang karna seringnya nggak paham "(P6)

\section{2) Pendidikan}

Selain usia, status pendidikan juga sangat mempengaruhi komunikasi yang ada. Adanya perbedaan tingkat pendidikan seseorang menjadikan setiap individu memiliki pemahaman yang berbeda dalam mencerna informasi yang diberikan. Hal ini seperti yang diungkapkan oleh 9 orang dari 10 informan bahwa mereka mengalami kesulitan saat berkomunikasi dengan keluarga pasien yang memiliki status pendidikan menengah ke bawah. Berikut adalah beberapa kutipan yang diungkapkan oleh informan

“....... gitu lah yang pendidikannya rendah gitu kan keliatan juga kan ya pas ngobrol susah nyambung ......” (P2)

“....... kalo yang latar belakang pendidikannya rendah gitu ya seringnya udah dijelasin nih terus masih aja nggak ngerti ......" (P4)

\section{3) Ekonomi}

Salah satu status sosial yang dapat mempengaruhi komunikasi yang ada adalah ekonomi. Hal ini dikarenakan dibutuhkan banyak pemikiran dan pertimbangan apabila menyangkut tentang pembiayaan mengingat hal ini merupakan sesuatu yang sensitif bagi keluarga pasien.

Dari hasil wawancara didapatkan 4 orang dari 10 informan menyatakan bahwa ekonomi mempengaruhi komunikasi antara mereka dengan keluarga pasien, seperti yang diungkapkan oleh informan di bawah ini

“....... kalo pemeriksaannya mahal ya wajar kan ya namanya juga berhubungan sama duit" (P2)

"....... masalah biaya sih ujung-
ujungnya ......" $(\mathrm{P} 3)$

\section{Kesalahpahaman}

Keragaman budaya dan bahasa sering kali menjadi hambatan seseorang dalam berkomunikasi. Hal ini dikarenakan setiap daerah memiliki perbedaan budaya dan bahasa yang tentunya akan berpengaruh dalam komunikasi antar individu.

Dari hasil analisa data muncul dua sub tema terkait kesalahpahaman komunikasi yang sering dialami oleh perawat dalam berkomunikasi dengan keluarga pasien di ICU yaitu budaya dan bahasa.

\section{1) Budaya}

Budaya setiap orang berbeda tergantung daerahnya masing-masing. Setiap daerah memiliki karakteristiknya masingmasing yang dapat mempengaruhi komunikasi yang ada antar individu. Adanya perbedaan budaya yang dirasakan oleh separuh dari informan dapat menimbulkan kesalahpahaman saat mereka berkomunikasi dengan keluarga pasien.

Dari 10 informan yang diwawancara 5 diantaranya menyatakan bahwa perbedaan 
intonasi sering menimbulkan perbedaan persepsi dan kesalahpahaman. Hal ini seperti yang diungkapkan oleh beberapa informan di bawah ini

“...... nah ngomongnya kan kenceng kan kadang-kadang keluarga jadi salah persepsi dikira marah-marah" (P4)

“....... dari segi intonasi pasti ada lah kaya emosi kita keangkat sedikit kalo kaya yang sama yang di luar Sunda .......” (P7)

“........ kan ngomongnya kenceng kan ya disangkanya paling nyentak-nyentak" (P8)

“....... suka jadi ada pikiran ko dia marah-marah sih atau dia galak, padahal mah nggak" (P10)

\section{2) Bahasa}

Setiap daerah bahkan setiap negara memiliki bahasanya masing-masing. Adanya perbedaan bahasa dapat mempengaruhi komunikasi yang ada. Beberapa informan menyatakan bahwa mereka mengalami kesulitan dalam berkomunikasi dengan keluarga pasien khususnya yang menggunakan bahasa asing seperti bahasa Inggris.

Dari 10 informan yang diwawancara 3 diantaranya mengungkapkan bahwa mereka mengalami hal tersebut sebagaimana diungkapkan di bawah ini

“...... ya gitu weh rada susah kan bahasanya juga beda kan mereka ngertinya bahasa Inggris sedangkan perawat ya nggak semua lancar ngomong bahasa Inggris" (P1)

“....... da kalo kitanya disuruh ngomong bahasa Inggris mah kan gitu neng susah di kitanya" (P2)

"....... ada aja sih yang pasien dari luar, ya pake bahasa isyarat ......" (P3)

"Ya kumaha deui kalo pake bahasa Inggris mah da susah" (P3)

\section{Lingkungan dan Situasi di ICU}

Keluarga pasien mempunyai karakteristik yang beragam baik itu usia, status pendidikan, maupun kultur budaya dan bahasa. Sebagai perawat tentunya dibutuhkan kemampuan dalam berkomunikasi dengan keluarga pasien.

Dalam hal ini softskill yang dibutuhkan adalah kesabaran. Kesabaran sangatlah diperlukan mengingat perawat berhubungan langsung dengan keluarga pasien. Hal ini seperti yang diungkapkan oleh 3 orang dari 10 informan yang diwawancara

“....... ngejelasinnya juga harus sabar ......" (P3)

"...... ya gitu sih harus lebih sabar kalo sama yang tua mah ....." (P6)

“...... ya harus sabar kitanya ......"

Profesi perawat merupakan salah satu profesi yang membutuhkan kesabaran yang tinggi. Hal ini dikarenakan perawat tidak hanya berhadapan dengan pasien tetapi juga keluarga pasien.

Sebagai seorang perawat kita dituntut untuk selalu sabar dalam kondisi apapun termasuk apabila menghadapi complain baik itu dari pasien maupun keluarga. Di ICU tak sedikit keluarga yang complain kepada perawat. Umumnya mereka complain mengenai jam besuk seperti yang diungkapkan oleh 3 orang dari 10 informan di bawah ini

“...... minta pengen bolak-balik liat pasien" (P1)

"...... jam besuk dibatasi itu sih yang paling sering jadi complain da aturannya udah seperti itu keluarga boleh masuk hanya pas jam besuk saja atau pas kondisi-kondisi tertentu" (P2)

“...... rata-rata sih complain jam kunjungan" (P9)

Selain mengenai jam kunjungan keluarga juga sering complain terkait perawat dengan membandingkan perawat satu dengan perawat lainnya. Hal ini sebagaimana diungkapkan oleh informan sebagai berikut

“....... ngebandingin kenapa perawat yang ini gini kenapa perawat yang itu gitu" (P8) 
“..... kenapa kalo kata perawat yang itu mah gitu kata perawat yang ini mah gini "(P8)

\section{Kondisi Psikologis Keluarga}

Kesulitan terkait pemberian informasi klinis yang dialami oleh perawat umumnya adalah karena keluarga masih denial atau belum bisa menerima mengenai penurunan kondisi pasien. Hal tersebut sesuai dengan hasil wawancara dimana 7 orang dari 10 informan menyatakan kesulitan saat menghadapi keluarga pasien yang masih belum dapat menerima penurunan kondisi pasien, seperti yang diungkapkan oleh beberapa informan di bawah ini.

“...... ya agak susah kalo merekanya sambil nangis atau bahkan sampe ada yang pingsan gitu aja sih ......" (P5)

“...... paling agak susah kalo keluarganya yang masih belum bisa menerima gitu sih ......" (P6)

“...... ada kesulitan kalo sama keluarga yang masih kurang bisa menerima" (P9)

“...... ya paling kalo yang keluarganya belum bisa menerima sih" (P10)

Dalam hal ini untuk menyikapi hal tersebut, beberapa informan menyatakan bahwa mereka biasanya akan mengalihkannya kepada dokter jaga atau DPJPnya langsung. Dari hasil wawancara, 3 orang dari 10 informan mengungkapkan bahwa mereka mengalihkan keluarga pasien yang masih belum bisa menerima kepada dokter jaga sebagaimana kutipan di bawah ini

“....... ya terus apabila keluarga pasien nggak nerima terus agak ribet juga kita panggil aja dokter jaga suruh menjelaskan karna lebih leluasa dan lebih banyak wewenangnya" (P1)

“....... biasanya kita minta bantuan ke dokter jaga untuk menjelaskan gitu atau DPJPnya langsung atau ditelepon" (P2)

“....... ya kita libatkan dokter jaga gitu sih ya untuk ngasih penjelasaan" (P9)

\section{Konflik Peran}

Keadaan tidak menyenangkan yang dialami oleh perawat dapat menimbulkan stres bagi perawat yang nantinya akan berujung pada terjadinya kejenuhan kerja (burnout). Ketidaknyamanan yang dialami perawat akan berdampak pada pelayanan yang diberikan mengingat perawat sebagai ujung tombak pelayanan kesehatan.

Padahal komunikasi nonverbal seperti senyuman dan juga ekspresi wajah sangatlah penting dalam menciptakan komunikasi yang efektif antara perawat dengan pasien dan keluarga (Xu, Staples, \& Shen, 2012).

Informan juga menyebutkan bahwa mereka mengalami konflik peran terkait kondisi psikologis dan fisik yang mereka alami dengan penampilan mereka dalam menyampaikan informasi kepada keluarga pasien. Hasil penelitian menyatakan 4 orang informan mengalami dilema komunikasi terkait hal tersebut.

Hal ini disebabkan oleh kelelahan yang mereka alami dan masalah pribadi yang mereka hadapi sehingga berdampak pada penampilan mereka seperti menjadi jarang senyum saat menyampaikan informasi kepada keluarga pasien.

Hal ini sesuai dengan penelitian yang dilakukan oleh Loghmani et al (2014) yang menyebutkan bahwa masalah pribadi yang terjadi dapat mengganggu interaksi antara perawat dengan keluarga pasien selain hal itu kekurangan staf ditambah dengan beban kerja yang tinggi menyebabkan perawat tidak mempunyai waktu yang cukup untuk keluarga pasien sehingga terjadilah interaksi negatif antara perawat dengan keluarga (Loghmani, Borhani, \& Abbaszadeh, 2014).

Hasil penelitian tersebut sesuai dengan penelitian lain di Iran yang menyebutkan tekanan pekerjaan berlebih sebagai salah satu yang menjadi hambatan dalam komunikasi selain penurunan motivasi perawat, dan ketidakpercayaan terhadap kompetensi perawat yang berhubungan dengan perbedaan budaya, perawat yang kurang tanggap, dan 
sikap apatis perawat terhadap pasien (Shafipour, Mohammad, \& Ahmadi, 2014). Idealnya perawatan di ruang intensif memiliki perbandingan 1:1 dimana satu orang perawat menangani satu orang pasien. Akan tetapi, kenyataan dilapangan menyebutkan bahwa terkadang mereka memegang dua orang pasien dalam sekali shift sehingga hal tersebut membuat mereka kelelahan.

Ketidaksesuaian jumlah perawat dengan jumlah pasien yang harus mereka rawat membuat perawat harus dapat beradaptasi dengan keadaan tersebut. Adaptasi yang terjadi bersifat buruk dikarenakan perawat akan terbiasa dengan hal itu sehingga perawat akan lupa untuk berkomunikasi dengan keluarga pasien sekalipun mereka sedang tidak sibuk.

Hal tersebut bertambah sulit ketika perawat sebagai ujung tombak pelayanan kesehatan harus berhubungan langsung dengan keluarga pasien yang berperan sebagai jembatan komunikasi antara perawat dengan pasien. Oleh karena itu perawat dituntut untuk selalu dapat bersikap profesional dalam berkomunikasi baik itu secara verbal maupun nonverbal.

Berdasarkan hasil penelitian, 4 orang informan menyebutkan bahwa pasien yang dirawat di ICU umumnya berada dalam kondisi tidak sadar sehingga keluarga yang menjadi penanggung jawab pasien baik itu suami, istri, atau anaknya. Tentunya dalam hal ini kelurga wajib menunggui pasien mengingat kondisi pasien di ICU yang dapat berubah sewaktu-waktu.

Akan tetapi pada kenyataannya sering kali keluarga tidak ada ditempat untuk menunggui pasien dengan alasan sibuk, mempunyai anak kecil, dan sebagainya sehingga menyulitkan perawat dalam memberikan informasi. Dari hasil penelitian didapatkan 3 orang informan menyatakan bahwa mereka mengalami kesulitan dalam hal komunikasi dikarenakan keluarga pasien tidak ada di tempat.
Hasil penelitian ini pun menunjukkan bahwa yang menjadi hambatan dalam komunikasi efektif antara perawat dengan keluarga pasien adalah faktor demografi keluarga seperti usia, latar belakang pendidikan, dan juga status ekonomi. Ketiga hal tersebut dapat mempengaruhi pola komunikasi yang ada.

\section{Faktor Demografi Keluarga}

Berdasarkan hasil penelitian, 7 orang informan menyatakan bahwa mereka mengalami kesulitan dalam hal usia terlebih apabila berkomunikasi dengan keluarga pasien yang usianya lebih tua. Penelitian yang dilakukan oleh Callinan dan Brandt (2015) menyebutkan bahwa hambatan perawat dalam berkomunikasi dengan orang lanjut usia dikarenakan adanya gangguan kognitif.

Oleh karena itu dibutuhkan teknik berkomunikasi yang sesuai dengan keadaan mereka seperti menggunakan bahasa yang sederhana dan berbicara dengan perlahanlahan. Selain hal itu, 9 orang informan menyatakan bahwa mereka mengalami kesulitan yang berhubungan dengan latar belakang pendidikan keluarga pasien.

Latar belakang pendidikan keluarga pasien mempengaruhi pemahaman mereka dalam mencerna informasi yang diberikan oleh perawat. Hal ini seperti yang dijelaskan dalam penelitian Astutik dan Widodo (2011) bahwa semakin tinggi pendidikan seseorang maka semakin mudah ia dalam menerima informasi yang diberikan petugas kesehatan begitupun sebaliknya.

Selain hal itu hasil penelitian menyebutkan bahwa 4 orang informan mengalami kesulitan yang berhubungan dengan status ekonomi keluarga pasien. Status ekonomi dapat mempengaruhi komunikasi yang ada dikarenakan diperlukan banyak pertimbangan sehingga keluarga membutuhkan waktu yang lebih lama untuk mengambil suatu keputusan, sedangkan hal tersebut dapat mempengaruhi dan menunda 
pemberian tindakan yang bersifat segera untuk pasien.

Hal ini sesuasi dengan penelitian yang dilakukan oleh Loghmani, et al (2014) yang menyatakan bahwa status ekonomi dapat mempengaruhi interaksi hubungan antara perawat dengan keluarga pasien dikarenakan terkadang keluarga pasien menolak tindakan yang disarankan karena masalah keuangan.

\section{Kesalahpahaman}

Selain faktor demografi keluarga, kesalahpahaman yang sering terjadi antara perawat dengan keluarga pasien juga menjadi hambatan perawat dalam berkomunikasi dengan keluarga pasien. Kesalahpahaman rentan terjadi pada profesi perawat yang berhubungan langsung baik itu dengan pasien maupun keluarga pasien.

Kesalahpahaman yang terjadi dalam komunikasi antara perawat dengan keluarga pasien dikarenakan adanya perbedaan kultur budaya dan bahasa. Hasil penelitian menyebutkan bahwa terdapat 5 orang informan yang menyatakan bahwa mereka sering mengalami perbedaan persepsi dan kesalahpahaman yang disebabkan oleh adanya perbedaan intonasi dalam berbicara, sedangkan 3 orang informan menyatakan bahwa mereka mengalami kesulitan berbahasa asing sehingga adanya perbedaan bahasa menghambat mereka dalam berkomunikasi dengan keluarga pasien.

Perawat mengalami kesulitan saat berbicara dengan seseorang yang mempunyai latar belakang budaya dan bahasa dengan kita. Penelitian lain yang dilakukan oleh Chittem dan Butow (2015) menyatakan bahwa adanya perbedaan bahasa dapat menyebabkan timbulnya kesalahpahaman dalam menfasirkan informasi yang diberikan.

Oleh karena itu dalam hubungan perawat-keluarga diperlukan sikap saling menghargai untuk dapat meminimalisir terjadinya kesalahpahaman karena adanya perbedaan kultur budaya dan bahasa.

\section{Lingkungan dan Situasi di ICU}

Tugas seorang perawat amatlah tidak mudah dikarenakan perawat berhubungan dengan banyak pihak baik itu pasien maupun keluarganya. Tentunya dalam hal ini dibutuhkan tidak hanya keterampilan tetapi juga kesabaran yang tinggi dalam menghadapi segala macam situasi dan kondisi.

Lingkungan dan situasi di ICU tentunya sangatlah berbeda dengan ruangan perawatan biasa. Hasil penelitian menyebutkan bahwa 3 orang informan menyatakan bahwa kesabaran sangat diperlukan dalam komunikasi antara perawat dengan keluarga pasien mengingat perawat berhubungan langsung dengan mereka. Penelitian yang dilakukan oleh Loghmani, et al (2014) menyebutkan bahwa pekerjaan perawat tidaklah mudah karena kita harus bisa mengontrol amarah sekalipun keluarga pasien berteriak kepada kita.

Sebagai seorang perawat kita dituntut untuk selalu dapat bersikap profesional saat bertugas. Hal ini ditunjukkan dalam situasi dan kondisi apapun termasuk di dalamnya adalah saat menghadapi complain baik itu oleh pasien maupun keluarganya.

Hasil penelitian menyebutkan bahwa 3 orang informan menyatakan bahwa mereka seringkali menghadapi complain keluarga khususnya masalah jam kunjungan, sedangkan 2 orang informan menyatakan bahwa mereka menghadapi complain keluarga yang membandingkan perawat satu dengan perawat lainnya.

Ketidaktaatan keluarga dan kerabat pasien dalam waktu kunjungan mengakibatkan interaksi negatif antara perawat dan anggota keluarga pasien (Loghmani, Borhani, \& Abbaszadeh, 2014). Keluraga masih merasakan kurangnya waktu mengunjungi pasien (Emaliyawati, 2011). Perawat mengeluh bahwa kunjungan yang dilakukan oleh anggota keluarga di luar jam berkunjung yang telah ditetapkan mengganggu pekerjaan mereka, pasien lain dan mengancam privasi mereka. 


\section{Kondisi Psikologis Keluarga}

Menyampaikan informasi kepada keluarga pasien dirasakan semakin sulit terlebih pada saat perawat harus menghadapi keluarga pasien yang denial. Dari hasil penelitian yang didapat 7 orang informan menyatakan bahwa mereka mengalami kesulitan saat menghadapi keluarga pasien yang denial atau belum dapat menerima keadaan pasien yang umumnya mengalami penurunan kondisi. Hal ini sesuai dengan penelitian yang dilakukan oleh Griffiths, et al (2015) yang menyatakan bahwa tidak mudah menyampaikan berita buruk kepada pasien atau keluarga terlebih kadang mereka memasuki fase dimana mereka belum dapat menerima keadaan yang ada.

Kesulitan dalam menghadapi keluarga pasien yang masih belum dapat menerima penurunan kondisi yang dialami pasien menjadikan perawat kemudian melimpahkan tugas dalam menyampaikan informasi kepada dokter jaga atau DPJPnya langsung. Hal ini diungkapkan oleh 3 orang informan bahwa mereka akan memanggil dokter jaga atau meminta bantuan kepada DPJPnya apabila keluarga pasien masih belum bisa menerima apa yang disampaikan oleh perawat.

\section{SIMPULAN}

Berdasarkan hasil penelitian yang telah dilakukan pada 10 orang responden yaitu perawat yang bekerja di ICU didapatkan hasil yaitu terdapat lima tema yang menjadi hambatan perawat dalam berkomunikasi dengan keluarga pasien yaitu konflik peran, faktor demografi keluarga, kesalahpahaman, lingkungan dan situasi di ICU, dan kondisi psikologis keluarga. Hasil penelitian ini menunjukkan bahwa terdapat banyak faktor yang menjadi hambatan perawat dalam berkomunikasi dengan keluarga pasien di ICU seperti konflik peran, faktor demografi keluarga, kesalahpahaman, lingkungan dan situasi di ICU, dan kondisi psikologis keluarga. Oleh karena itu menjadi penting untuk mengadakan pelatihan-pelatihan terkait komunikasi perawat untuk meningkatkan kemampuan perawat seperti kemampuan berbahasa asing dan kesabaran dalam menghadapi situasi dan kondisi di ICU khususnya berhubungan dengan keluarga pasien.

\section{DAFTAR PUSTAKA}

Afiyanti, Y., \& Rachmawati, I. (2014). Metodologi Penelitian Kualitatif Dalam Riset Keperawatan. Jakarta: PT. Raja Grafindo Persada.

Chittem, M., \& Butow, P. (2015). Responding To Family Request For Nondisclosure : The Impact Of Oncologists'cultural Background. Journal of Cancer Research and Therapeutics Vol. 1.

Depkes. (2006). Standar Pelayanan Keperawatan di ICU. Retrieved Januari Jumat, 2016, from Perpustakaan DEPKES:

https://www.perpustakaan.depkes.go.id

Emaliyawati, E. (2011). Interaksi Pasien, Keluarga, Dan Petugas Kesehatan Dalam Perawatan Hidup Pasien Terminal. ResearchGate.

Kepmenkes. (2010). Keputusan Menteri Kesehatan Republik Indonesia Tentang Pedoman Penyelenggaraan Pelayanan Intensive Care Unit (Icu) Di Rumah Sakit. Retrieved Januari Jumat, 2016, from http://badanmutu.or.id

Liljeroos, M., Snellman, I. M., \& Ekstedt, M. H. (2011). A Qualitative Study on The Role of Patient-Nurse Communication in Acute Cardiac Care. Journal of Nursing Education and Practice Vol.1, No. 1.

Loghmani, L., Borhani, F., \& Abbaszadeh, A. (2014). Factors Affecting The NursePatient's Family Communication In Intensive Care Unit of Kerman : Qualitative Study. Journal of Caring Sciences, 67-82.

Polit, D. F., \& Beck, C. T. (2014). Essentials Nursing Research : Appraising Evidence For Nursing Practice. Philadelphia: 
Wolters Kluwer Health : Lippincott Williams \& Wilkins.

Shafipour, V., Mohammad, E., \& Ahmadi, F. (2014). Barriers to Nurse-Patient Communication in Cardiac Surgery Wards : A Qualitative Study. Global Journal of Health Science, Vol. 6, No. 6.

Sugiyono. (2014). Metode Penelitian Kuantitatif, Kualitatif, Dan $R \& D$. Bandung: Alfabeta.
Suryani. (2014). Komunikasi Terapeutik : Teori \& Praktik, Ed. 2. Jakarta: Penerbit Buku Kedokteran EGC.

Xu, Y., Staples, S., \& Shen, J. J. (2012). Nonverbal Communication Behaviors of Internationally Educated Nurses and Patient Care. Research and Theory for Nursing Practice : An International Journal, Vol. 26, No. 4 